\title{
Silvicultural intensification for tropical forest conservation: a response to Fredericksen and Putz
}

\author{
PLINIO SIST ${ }^{1, *}$ and NICK BROWN ${ }^{2}$ \\ ${ }^{1}$ Forestry Department of CIRAD, Convênio EMBRAPA-CIRAD, Belem-PA 66095-100, Brazil; \\ ${ }^{2}$ Oxford Forestry Institute, Department of Plant Sciences, Oxford University, UK; *Author for \\ correspondence (e-mail: plinio@cpatu.embrapa.br; fax: +55-91-276-79-39)
}

Received 5 May 2004; accepted in revised form 13 May 2004

\section{Introduction}

In their recent paper Fredericksen and Putz (2003) (henceforth F \& P) recognize the necessity to minimize unnecessary logging perturbations, but claim that reduced impact logging (RIL) techniques create insufficient disturbance to permit regeneration of some commercially valuable timber species. They argue that in tropical forests where a valuable species requires substantial disturbance for seedling establishment, intensive silviculture, consisting mainly in increasing canopy gaps, is necessary in order to maintain a sustainable flow of timber. We argue that tropical forest silviculture for the sustainable management of its resources is much more complex than the manipulation of gap size. We take issue with a number of claims made by $\mathrm{F} \& \mathrm{P}$.

\section{Most tropical forests are not shaped by substantial disturbances}

F \& P appear to have confused a simple model of forest regeneration dynamics with the claim made by some environmental groups that natural forests are fragile, pristine environments that should be protected from any disturbance. Aubréville's (1938) mosaic theory of regeneration proposed that rather than consisting of stable plant associations, tropical rainforest was composed of a patchwork of seral stages. This patchwork is created by a sequence of disturbances that vary in their magnitude. The resultant gaps of different sizes and stages of regrowth are an important source of species diversity of tropical rainforests (Brokaw 1985). F \& P's claim that this paradigm has recently been superseded by a type of ecological catastrophism is fallacious. Large disturbances are known to play an important part in structuring forests in the Caribbean, parts of Central America and Pacific islands (Whitmore 1989; Brokaw and Walker 1991; Tanner et al. 1991). Furthermore, there is evidence that many (if not most) tropical rainforests experience infrequent large 
disturbances (Whitmore and Burslem 1998). However, it is wrong to imply that this is the predominant scale of disturbance determining the structure and composition of most tropical rainforests. Their low frequency and rapid forest recovery (e.g. Nelson et al. 1994) mean that their impact is transitory (Burslem et al. 2000).

\section{RIL creates adequate disturbance for the regeneration of many valuable timber species}

RIL techniques do not mimic natural disturbance regimes: they are imposed on top of them. The proportion of trees killed by harvesting operations under RIL techniques vary between $7 \%$ in the Amazon to $15 \%$ of the original stand in southeast Asia (Sist 2000). Logged forests also suffer a much higher natural mortality during the $2-5$ years following RIL than primary forest $(5 \%$ p.a. versus 1\% p.a.; Sist and Nguyen-Thé 2002). In southeast Asian dipterocarp forest the disturbance created by RIL ( 8 harvested trees/ha but $75-80 \%$ of the original basal area remaining) was enough to stimulate rapid dipterocarp seedling growth for several years after logging (Sist and Nguyen-Thé 2002). In contrast, in intensively logged and damaged stands $(33 \%$ of the original tree population killed and less than $75 \%$ of the original basal area remaining), dipterocarp regeneration was much poorer (Sist and Nguyen-Thé 2002). Forest dynamics modelling suggested that RIL of moderate intensity would also permit a sustainable harvesting rotation of 40 years (volume of about $60 \mathrm{~m}^{3} / \mathrm{ha}$ at each harvest) while with RIL under higher extraction rates and damage, rotation increased to more than 60 years with a substantial risk of favouring pioneer species (Sist and Nguyen-Thé 2002; Sist et al. 2003c).

\section{Regeneration is about more than just gap size}

One important development that Fredericksen and Putz (2003) have ignored is the recognition that gap size is only one of many influences on patterns of rainforest regeneration. The gap-phase regeneration paradigm assumed that the most competitive plant was the one that had the greatest relative growth rate in response to the ambient light environment (Denslow 1980). Field experiments have shown that tall plants are able to capture more light and consequently grow faster and cast shade on the shorter plants beneath them. As a consequence, regeneration is often dominated by the tallest plants in a gap, regardless of their species (Brown and Whitmore 1992). When the seedling bank and all advance regeneration is destroyed by a disturbance, the first plants to re-colonise a gap will often pre-empt the light and delay or inhibit further colonisation by other species. In large gaps these are typically pioneer species that have widely dispersed seeds and a persistent soil seed bank. For silvicultural systems that depend on natural regeneration it is therefore crucial 
that the forest is already well stocked with abundant seedlings and advance regeneration of desirable species prior to logging. It is also important that logging does not destroy those seedlings. F \& $\mathrm{P}$ argue that many important commercial species such as Swietenia macrophylla, Entandrophragma spp. and Shorea leprosula require big gaps or even catastrophic disturbance to regenerate. However, a number of experimental studies have shown that these species have poorer germination and establishment in very open conditions than in partial shade (Nicholson 1960; Nussbaum et al. 1995; Kyereh et al. 1999; Morris et al. 2000; Hall et al. 2003), making it difficult for them to establish naturally in large felling gaps. In mixed dipterocarp forests, experiments have also shown that gaps should be limited to $\leq 500-650 \mathrm{~m}^{2}$ to favour dipterocarp regeneration and to limit pioneer invasion (see Sist et al. 2003b).

Past experience suggests that substantial opening of the forest canopy typically triggers vine and pioneer infestations while they fail to stimulate the regeneration of valuable commercial light-demanding species (Lancaster 1961; Britwum 1976; Lowe 1978; Wyatt-Smith 1988; Bruenig 1996). Moreover, large canopy openings significantly increase forest flammability, particularly during long periods of drought such as those that occur in southeast Asia during El Niño events (Dennis 1999). Another factor which F \& P have failed to take account of is that commercially valuable timber species occur in forests across a range of climate types and their responses to disturbance vary accordingly. For example, Entandrophragma utile regenerates in large gaps in high forest in the south of Ghana, but in the drier north is restricted to moist shaded areas away from direct sunlight (W. Hawthorne, personal communication). Swietenia macrophylla is a species that regenerates profusely in the more open conditions found in the transition zone from open deciduous forest to evergreen rainforest (Brown et al. 2003). In the deciduous forests, small-scale disturbances created by controlled logging will be enough to stimulate natural regeneration (Brown et al. 2003). In high forests where S. macrophylla persists as relic populations typically represented by very few adults and rare seedlings and saplings (Grogan et al. 2002; Brown et al. 2003), large disturbances may be necessary for natural regeneration. However, in this type of population, it is also absolutely essential to leave sufficient adult trees to ensure reproduction and therefore seed production (Jennings et al. 2001). Indeed, the creation of a favourable microclimate for regeneration is useless if reproduction processes are not preserved, an essential point that $\mathrm{F} \& \mathrm{P}$ did not address at all.

\section{Conclusions}

Whilst there is evidence that many humid tropical forests have experienced large disturbances in the past, very few commercially important species require cataclysmic disturbance for regeneration. Recent research has shown that RIL techniques are necessary for sustainable harvesting but not sufficient on their own to guarantee that it occurs (especially when based solely on minimum 
diameter cutting limits) (Sist et al. 2003a, b). Intensive silviculture (meaning the rigorous application of skilled forest management as opposed to substantial opening of the forest canopy) is urgently needed to stimulate the regeneration and growth of many valuable commercial species, not just the most lightdemanding ones. This is a complex task which cannot be reduced simply to the manipulation of felling gap sizes. Large gaps may promote fast growth by a small number of light-demanding species, but they have other ecological ramifications which may not be beneficial for sustainable production. Threshold levels of damage that can be sustained in the long term have only been quantified for a small number of tropical forests (e.g. a harvesting threshold of 8 trees/ha, and maximum gap size of $600 \mathrm{~m}^{2}$ for mixed dipterocarp forest, Sist et al. 2003a, b; or one third of the original basal area in French Guiana, Gourlet-Fleury, personal communication). But without a good understanding of these thresholds, general recommendations such as F \& P's proposal to increase gap sizes in order to favour a few light-demanding timber species, may have disastrous and irreversible effects on forest recovery after logging.

Most experiences over the last century in tropical rainforests around the World show that intensive silviculture was neither effective nor sustainable. Tropical forestry has been dominated by western silvicultural concepts that mainly aimed to favour a limited number of species while eliminating noncommercial ones. In contrast, we believe that modern silviculture should maintain and promote the extremely high diversity of tropical forest, as it represents an important biological and potential economical value for the future.

\section{Acknowledgements}

We are grateful to Sylvie Gourlet-Fleury, Eric Forni, Robert Nasi and Peter Savill for their comments and inputs to an earlier draft.

\section{References}

Aubréville A. 1938. La forêt coloniale: les forêt de l'Afrique occidentale francaise. Annales Academie des Sciences Coloniale, Paris 9: 1-245.

Britwum S.P.K. 1976. Natural and artificial regeneration practices in the high forest of Ghana. Ghana Forestry Journal 2: 45-49.

Brokaw N.V.L. 1985. Gap-phase regeneration in a tropical forest. Ecology 66: 682-687.

Brokaw N.V.L. and Walker L.R. 1991. Summary of the effects of Caribbean hurricanes on vegetation. Biotropica 23: 442-447.

Brown N., Jennings S. and Clements T. 2003. The ecology, silviculture and biogeography of mahogany (Swietenia macrophylla): a critical review of the evidence. Perspectives in Plant Ecology, Evolution and Systematics 6: 37-49.

Brown N.D. and Whitmore T.C. 1992. Do dipterocarp seedlings really partition tropical rain forest gaps? Philosophical Transactions of the Royal Society London B 335: 369-378. 
Bruenig E.F. 1996. Conservation and Management of Tropical Rain Forest: An Integrated Approach to Sustainability. CAB International, Wallingford, UK.

Burslem D., Whitmore T.C. and Brown G.C. 2000. Short-term effects of cyclone impact and longterm recovery of tropical rain forest on Kolombangara, Solomon Islands. Journal of Ecology 88: 1063-1078.

Dennis R. 1999. A review of fire projects in Indonesia (1982-1998). CIFOR, Bogor, Indonesia.

Denslow J.S. 1980. Gap partitioning among tropical rain forest trees. Biotropica 12: 47-55.

Fredericksen T.S. and Putz F.E. 2003. Silvicultural intensification for tropical forest conservation. Biodiversity and Conservation 12: 1445-1453.

Grogan J., Barreto P. and Verissimo A. 2002. Mahogany in the Brazilian Amazon: Ecology and Perspectives on Management. Imazon, Belém, Pará, Brazil.

Hall J.S., Medjibe V., Berlyn G.P. and Ashton P.M.S. 2003. Seedling growth of three co-occurring Entandrophragma species (Meliaceae) under simulated light environments: implications for forest management in central Africa. Forest Ecology and Management 179: 135-144.

Jennings S.B., Brown N.D., Boshier D.H., Whitmore T.C. and Lopes J.d.C.A. 2001. Ecology provides a pragmatic solution to the maintenance of genetic diversity in sustainably managed tropical rain forest. Forest Ecology and Management 154: 1-10.

Kyereh B., Swaine M.D. and Thompson J. 1999. Effect of light on the germination of forest trees in Ghana. Journal of Ecology 87: 772-783.

Lancaster P.C. 1961. Experiments with natural regeneration in the Omo forest reserve. Nigerian Forestry Information Bulletin (n.s.) 13: 5-16.

Lowe R.G. 1978. Experience with the tropical shelterwood system of regeneration in natural forest in Nigeria. Forest Ecology and Management 1: 193-212.

Morris M.H., Negreros-Castillo P. and Mize C. 2000. Sowing date, shade and irrigation affect bigleaf mahogany (Swietenia macrophylla King). Forest Ecology and Management 132: 173-181.

Nelson B.W., Kapos V., Adams J.B., Oliveira W.J., Braun O.P.G. and do Amaral I.L. 1994. Forest disturbance by large blowdowns in the Brazilian Amazon. Ecology 75: 853-858.

Nicholson D.I. 1960. Light requirements of seedlings of five species of Dipterocarpaceae. Malaysian Forester 23: 344-356.

Nussbaum R., Anderson J. and Spencer T. 1995. Factors limiting the growth of indigenous tree seedlings planted on degraded rain-forest soils in Sabah, Malaysia. Forest Ecology and Management 74: 149-159.

Sist P. 2000. Reduced-impact logging in the tropics: objectives, principles and impact of research. International Forestry Reviews 2: 3-10.

Sist P. and Nguyen-Thé N. 2002. Logging damage and the subsequent dynamics of a dipterocarp forest in East Kalimantan (1990-1996). Forest Ecology and Management 165: 85-103.

Sist P., Sheil D., Kartawinata K. and Priyadi H. 2003. Reduced-impact logging in Indonesian Borneo: some results confirming the need for new silvicultural prescriptions. Forest Ecology and Management 179: 415-427.

Sist P., Fimbel R., Nasi R., Sheil D. and Chevallier M-H. 2003b. Towards sustainable management of mixed dipterocarp forests of South East Asia: moving beyond minimum diameter cutting limits. Environmental Conservation 30: 364-374.

Sist P., Picard N. and Gourlet-Fleury S. 2003c. Sustainable rotation length and yields in a lowland mixed dipterocarp forest of Borneo. Annals of Forest Science 60: 803-814.

Tanner E.V.J., Kapos V. and Healey J.R. 1991. Hurricane effects on forest ecosystems in the Caribbean. Biotropica 23: 513-521.

Whitmore T.C. 1989. Changes over 21 years in the Kolombangara rain forests. Journal of Ecology 77: 469-483.

Whitmore T.C. and Burslem D.F.R.P. 1998. Major disturbances in tropical rainforests. In: Newbery D.M., Prins H.H.T. and Brown N. (eds), Dynamics of Tropical Communities. Blackwell Science, Oxford, UK, pp. 549-565.

Wyatt-Smith J. 1988. Letter to the Editor. Forest Ecology and Management 24: 219-223. 